\title{
MANAGEMENT IN EDUCATIONAL SECTOR OF UKRAINE
}

\section{Dolzhenkov O. A.}

\section{INTRODUCTION}

Management in educational sector has its own specifics and regularities that are inherent only to it. In Ukraine, the study of the problems of managerial activity in education (emphasis on psychological problems) began in the early 70's of the twentieth century. It mainly aimed at: studying the psychological prerequisites for optimizing the leadership of the pedagogical staff of the school and creating a favorable, creative socio-psychological and business climate in it; the influence of the personal qualities of the school principal (director), his style of leadership on cohesiveness and professional capacity of the teaching staff; the quality of the educational process; psychological competence of managers and forms and methods for raising its level; motivation of directors of general educational institutions (secondary schools) to increase the level of management activity, etc. (G. Yelnikova,
L. Kalinina,
L. Karamushka,
N. Kolominskii,
S. Moskvichov,

G. Polyakova, S. Sysoev, R. Shakurov and others).

The efforts of many well-known scholars are directed at the study of education management problems: E. Berezniak (features of management of a modern school), V. Bondar (didactic aspects of the managerial activity of the school principal), L.Vaschenko (system of management of innovative processes in the general secondary education of the region), L. Danilenko (socio-pedagogical aspect of the efficiency of management of the general school), O. Elbrecht (adaptive management of the educational process of a secondary school), Y. Konarzhevsky (pedagogical analysis of school management), O. Marmaza (management in education), V. Maslov (theoretical foundations of pedagogical management), L. Orban-Lembrik (acmeological aspects of professional management), V. Pikel'naya (school management and modeling of managerial activities), V. Sukhomlinsky (peculiarities of the professional activity of the school principal), E. Hrykova (management of an educational institution), T. Shamova (management of educational systems 
in an adaptive school), and others. Most of their works relate to the system of general secondary and postgraduate education.

Currently, there are quite a few publications devoted to the professionalism and professional competence of the manager of a comprehensive educational institution, and ways of improving and improving the effectiveness of his management activities are offered.

The dynamics of development of educational sphere throughout last years shows some drastic alternations that take place. The sphere of management of educational institutions is characterized by a saturation with human resources, that often results in contradiction of interests between separate persons, as well as large and small groups. For quick and, at the same time, effective resolution of such problems a manager should posess theoretical knowledge and practical skills in the sphere of a complex decision of business conflicts. From the scientific point of view the problem of starting and development of business conflicts was researched by such scientists as: V. Andrianov, A. Bandurina, B. White, A. Dmitrieva, V. Druzhinina, Y. Zaprudskiy, A. Kitov, H. Kornelius, N. Kroshus, V. Kudryavtseva, K. Levin, G. Lozhkin, D. Mayers, J. Piapoe, O. Sannikova, V. Semichenko, J. Scott, S. Fayre and others.

Actuality of this issue is predefined by the fact that researches of business conflicts in the sphere of the management of educational institutions up to this time has had mainly situative character. According to this, research of theoretical aspects connected with the features of managing business conflicts is a necessity.

\section{Management and administration in general education of Ukraine}

Manager of an educational institution is a person who professionally manages the organizational system and the staff of an educational institution within the framework of his duties at different levels of management. The modern manager of the educational institution not only honestly performs his professional duties. He is aimed at the future in his professional activities. His professional (managerial) activity is in its essence acmeological.

The acmeologic activity of the manager is the activity aimed on the improvement and development of his own acmeological abilities and managerial skills in order to increase the effectiveness of management of the organizational system. Managerial activity is a purposeful, selforganized social-psychological system, the unity of interconnected 
structural and functional components that are associated with solving managerial tasks to achieve the main goals of the organization.

The most significant features of managerial activity are:

1. Supporting in optimal operating mode the control systems that are complex in their elements and heterogeneous in function of objects (target). Effective functioning of management systems is based on: planning, control, correction, adaptation, emotional identification, consolidation.

2. The object of managerial activity is an organization whose hierarchical structure can be one-component and multi-component.

3. There is a constant functional relationship between professional positions, which determines the relationship between people who appear to be the bearers of these positions.

4. Direction for optimization of managerial activity with the help of economic, administrative, psychological, psychotherapeutic and pedagogical influences.

5. Reception, processing information and generating new information in the form of managerial decision.

6. As the main way of presenting information in managerial activities, indicators and means for describing the characteristics of an object of management, functional and causal relationships between its elements, between the object of management and the environment are used.

7. Relating the generated information to other people.

8. Direct involvement of the subject of managerial activities in the performance of his own solution to professional problems ${ }^{1}$.

The main tasks of managerial activity are the following:

- definition of the main goal and objectives tree, formation and corresponding formulation of the strategy of action for achievement of the general goal, formulation of the concept of development and activity of the corresponding organization (educational institution);

- staffing around the general organizational purpose;

- social and professional motivation of personnel for the purposes of the organization and solving problems that arise once or twice depending on the situation;

${ }^{1}$ Деркач А.А. Акмеологические основы управленческой деятельности. Москва, 2000. Т. 2. $536 \mathrm{c}$. 
- formation, maintenance and correction (if necessary) of organizational order in an educational institution, the requirements of which are documented;

- development and implementation of the latest management technologies;

- diagnostics of control for determining the points of maximum and minimum controllability;

- the formulation of managerial decisions and a clear idea of the ways and the course of their implementation;

- implementation of managerial decisions and regulation of this process;

- development and implementation of control system for the implementation of managerial decisions.

Considering the manager of education as a subject of management activity, N. Kolominsky identified groups of abilities that are necessary for the successful management of their functions ${ }^{2}$ : diagnostic, predictive, design, organizational, communicative, comparative-assessment, academic, emotional-volitional. Also, the scientist highlights such professionalimportant qualities of managers-professionals of educational institutions: analytical-synthetic ability (diagnostic ability); imagination abilities, anticipation (prognostic and design abilities); altruism, empathy, reflection (organizational and communicative abilities); criticality of mind, predisposition to comparison (comparative-assessment abilities); flexibility and depth of thinking (gnostic abilities); social vigor, internality, endurance (emotional and volitional abilities). It is the presence of a unique ensemble of such qualities that allows the head of a general educational institution to skillfully perform his or her professional functions.

Professionally important qualities of a manager of the educational institution determine the style of his management. There are three main classical individual styles: authoritarian, democratic and liberal.

The authoritarian leadership style is characterized by the maximum centralization of the power of the leader in his hands. This style corresponds to the subject-object (technocratic) model of the interaction of the manager with subordinates whose essence is the absolute lack of interest to the employee as to personality. Democratic (collegial) style of

2 Коломонський Н.Л. Психологія менеджменту в освіті (соціальнопсихологічний аспект) : автореф. дис. ... д. псих. наук : 19.00.05. Київ, 2001. 37 с. 
management corresponds to the subject-subjective (human) model of interaction. The liberal-anarchist style of leadership corresponds to the object-subjective model of the interaction of the manager with subordinates.

In addition to these three main styles, one can distinguish the liberalpermissive (participative) style of leadership, which has the following features: regular meetings of the head with subordinates, openness in relations between the leader and subordinates, the delegation of a number of powers, rights, etc to the subordinates. The role of a manager is reduced to the functions of a consultant, coordinator, organizer, supplier.

Participative style is used, if the manager is confident, has a high educational and creative level, is able to appreciate and use the creative proposals of the subordinates; subordinates have a high level of knowledge, skills, need for creativity, independence, personal growth, interest in work ${ }^{3}$. The model of the interaction of the manager with subordinates is also object-subjective.

The style of the head of the educational institution naturally forms the style of work of the staff of the institution headed by him (a separate structural unit of the institution). Therefore, it is important to develop democratic principles at all levels of the managerial process at an educational institution.

By critically analyzing the factors of productivity of professional activity, the scientists - acmeologists N. Kuzmina, S. Pozharsky and L. Pautova believe that the acmeological factors ignificantly influence the managerial activity: increasing the productivity of such activity (enthusiasm for it), increasing the quality of joint activity of the employees (professional-personal self-development), increasing the productivity of creative activity (self-realization of creative potential in the activity) ${ }^{4}$.

The specificity of managerial activity is also determined by the external and internal conditions in its course. Among the external conditions should be distinguished: clearly defined time constraints,

3 Тищенко О.І. Феномен керівництва та лідерства в системі управлінської діяльності. URL: http://www.nbuv.gov.ua/portal/soc_gum/pfto/2010_9/ files/pd910_31.pd (дата звернення: 01.06.2019)

4 Кузьмина Н.В., Паутова Л.Е., Пожарский С.Д. Акмеология качества профессиональной деятельности специалиста : монография. Санкт-Петербург, 2008. $376 \mathrm{c}$. 
constant informational uncertainty, high responsibility for final results and subordinates, unregulated labor, lack of material, financial, information resources, work in extreme and stressful situations, etc. The internal conditions include: simultaneous solving of many tasks, controversy and often uncertainty of regulation requirements, lack of clearly formulated criteria for assessing the effectiveness of activities, diverse subordination of the head to various higher authorities, etc.

The effectiveness of the managerial system is determined by the follows: competence, perspective, completeness and clarity of setting general and specific goals, as well as specifying the tasks of development of a managed level; formation of subordinate joint production interests, goals and actions for the implementation of the tasks set; clarity of organization of the headed collective; completeness and prospects of planning and high level of implementation of the plan, control and adjustment; high professional competence, organization, democracy, tolerance, responsibility for the state of affairs, perseverance ${ }^{5}$.

According to N. Kolominsky, the essence of educational management is the conscious interaction of the manager with subordinates, partners, their leaders, pupils, parents, representatives of the public, which is aimed at achieving the stated goal. The object of management in education is the process of management of educational institutions. Its effectiveness depends directly on the quality of managerial activity of the manager of a comprehensive institution.

Viewing the peculiarities of managerial activity in the conditions of reforming the modern education of Ukraine, as well as the characteristic features of the current state of the system of education management and ways of its further modernization, it is worth to mention that the success of the manager is determined by the presence of such qualities: a broad outlook, a sense of the situation, a creative attitude to work, readiness for change, professional mobility, the desire for cooperation, self-motivation and motivation of personnel to achieve productive results, the ability to predict the results of professional activity (anticipation), ability to take risks, positive attitude not only to work and employees, but also to oneself, logical thinking, ability to act independently, ability to take

${ }^{5}$ Педагогіка : модульний курс / І.П. Анєнкова та ін. Львів : Новий Світ, 2010. $567 \mathrm{c}$ 
responsibility for himself, etc. The presence of such a set of qualities determines the ideal model of the manager.

Of course, practice shows that such an ideal is unattainable, but it makes sense to form such an ideal to identify the possibilities for their achievement. And this can be helped by the knowledge and practical consideration of the acme-synergetic grounds for the development of the personality of the professional manager, especially in such an important field as education. Practical formation and development of these qualities are based on the works of F. Genov (peculiarities of the work of managers with the definition of the specifics of the lower and middle levels of management), K. Muzdibayeva (theoretical analysis of responsibility as a psychic phenomenon), M. Savchina (psychology of responsible behavior) etc.

Considering the issue of effective managerial work, we could outline and stress three groups of qualities that must be strictly inherent to the manager as a leader, manager, and organizer: personal (honesty, modesty and justice in respect to others, good physical and mental health, emotional maturity, positive attitude to life and professional work), professional (general and managerial competence; general, technical, economic, legal, informational, psychological, pedagogical culture, high education and creativity, the ability to mobilize in case of emergency, predictability), organizational and business (purposefulness, business activity, discipline and high self-control, high efficiency, communication skills, contact, realism and charisma, tolerance to the weaknesses of subordinates, ability to manage, organize and support the work of the team, be ready for action, risk).

Summing up the analyzed material on the essence of the professional (managerial) activity of the head of a general educational institution, it should be noted that, with all the diversity of its officials, all of them are united by the fact that each function carried out is transformed through its own understanding and attitude towards oneself and others (subordinates, employees, students). Management is a complex multifaceted process of interrelated functions. The structure of management does not remain unchanged, it is characterized by mobility (mobility and changeability).

$\mathrm{V}$. Maslov identifies such functions of management in education as: socio-political, cultural-educational, managerial educational, management of the teaching process, administrative, economic and financial, and 
teaching ${ }^{6}$. V. Zvereva emphasizes the following components in the activities of the school's director: organizational-pedagogical, educational, publicorganizational, instructional, methodical, administrative and administrative, financial and economic. In addition, she defines organizational and pedagogical activity as a cyclical one, which is implemented through four stages -1 ) the choice and formulation of the purpose of activity, the choice of means for its implementation; 2) the selection and training of performers, 3) the definition of organizational relationships between them, 4) the evaluation of the results of activities ${ }^{7}$. Others offer very similar list of managerial functions which usually includes: planning, organization, regulation, adjustment, accounting and control, pedagogical analysis, stimulation.

Functions of management - these are activities that are clearly segregated both on the basis of the time of their implementation, and on managerial tasks. Such functions are related to the tasks of the development of an educational institution, and the functions of the manager are connected both with the tasks of development, and with the current tasks. Managerial functions are fundamental, unchanged types of managerial activities that reflect the overall logic of management. The functions of the manager of the educational institution are related to the current situation, the peculiarities of the educational institution, the peculiarities of the educational paradigm, and they are more variable.

\section{Management of business conflicts in an educational institution}

During the last years the sufficient amount of interesting and important researches is conducted in relation to the problems of business conflicts. There is a prooved increase of interest for the study of problem of conflict, however as yet a systematic research in separate directions is insufficient.

Before examining the features of business conflicts in educational institutions, it worth to mention that there are plenty of theories and wide range of approaches to concepts of "conflict" and "business conflict".

For the first time concept of "conflict" as multilevel social phenomenon was studied by Adam Smith in his famous work "Research about nature and

6 Маслов В.І. Наукові основи та функції управління загальноосвітніми навчальними закладами. Тернопіль : Астон, 2007. 150 с.

${ }^{7}$ Маслов В.І. Принципи менеджменту в установах освіти. Освіта і управління. 1997. Вип. 1. С. 77-84. 
reasons of riches of nations". A. Smith examined conflicts between opposing social classes as a source of development of society ${ }^{8}$.

Later W. Fisher determined a conflict a state of shock and disorganization in comparison with previous development that is the generator of new structures ${ }^{9}$.

Founder of independent direction in the study of conflicts in American sociology and conflictology W. Lincoln considered conflict from the position of pragmatism. In his opinion, a conflict is understanding, imagination or realizing by any single side the fact that other side or sides ignore or violate its interests ${ }^{10}$.

A. Antsupov determines a conflict through the selection of the stages of conflict: the base-line state, pre-conflict state, conflict state, transitional state, state of fixing of result of conflict ${ }^{11}$.

O. Kravchenko characterizes a conflict as situation in which the oppositely directed forces of approximately equal size influence on an individual simultaneously ${ }^{12}$.

D. Zelke worked out the theory of social conflict, according to which, a conflict is a fight around the values and solicitations caused by the deficit of status, power and tools, in which aims of opponents are being neutralized by their rivals ${ }^{13}$.

Thus, a conflict is the very difficult social and psychological phenomenon, successful study of which greatly depends on quality of methodological and theoretical pre-conditions and methods that is used.

Provided the general description of conflict, it seems necessary to precise such concepts as a "social conflict", "business conflict", "conflict situation".

In the sociological dictionary of Y.Babosov the completest determination of social conflict is given: a social conflict is a case of maximum intensication of social contradictions, that is expressed in the conflict of interests of different social associations, - classes, nations,

\footnotetext{
$205 \mathrm{c}$.

${ }^{9}$ Фишер Р. Путь к согласию. Москва, 1990. 312 с.

10 Линкольн У. Переговоры. Рига, 1998. 189 с.

${ }_{11}^{11}$ Анцупов А.І., Шипілов А.І. Конфліктологія. Москва : ЮНІТІ, 2000. 551 с.

12 Кравченко О.П. Погляд конфліктолога на онтосинтез конфлікту. Соціологічні дослідження. 2004. Вип. 9. С. 103-112.

13 Зельке Д.С., Віллерман М. Конфлікти та їх розв'язання у початковій школі. Суми, 1992. 164 с.
}

${ }^{8}$ Сміт А. Дослідження про природу і причини багатства народів. Москва, 1993. 
states, different social groups, and institutes, caused by opposition or difference of their interests, aims, progress trends" ${ }^{14}$.

Analysing scientific works related to origin and features of conflict situations, it could be generalized, that a conflict situation is interaction of the conflicting parties caused by an incident or occasion. A conflict situation is begun with an occasion. At the same time, an occasion is external, well realized reason of conflict. An occasion comes out in the form of claims.

N. Grishina points out that business conflict has a subject-object contradiction is the basis. Contradictions can exist for the long period and not to come out in a conflict. It is therefore necessary to consider that only incompatible contradictions, based on interests, necessities and values, could lie in basis conflict. Such contradictions, as a rule, are transformed in the open fight of parties, in the real opposing. Thus, a business conflict is the conflict based on contradictions directly in the sphere of professional activity ${ }^{15}$.

Therefore, a business conflict, as well as social, is unfolded and resolved in a certain situation connected with the origin of problem that requires a decision; both types of conflict have certain reasons, transmitters, own certain functions, duration and level of sharpness. However unlike social, a business conflict arises up only in the case when professional interests are at stake. At the same time, a conflict situation is only the fragment of conflict, episode of its development. However, sometimes the structure of conflict can be examined according to the structure of conflict situation.

Taking into account the above-mentioned, it is necessary to determine the structure of business conflict. With reference to scientific views of A. Dontsova, a structure of business conflict is the following:

1. Basic participants of conflict are those subjects of conflict, that directly act against each other. Opposite parties are a key link of conflict. When one of parties goes out of a conflict, then it ceases. It is also possible to mark a side that began a conflict - initiator, but in the protracted conflicts, doing it is more difficult. In a business conflict one distinguish important description of opponent - level. It is a level of possibilities of opponent from realization of the aims in a conflict, that is

\footnotetext{
${ }^{14}$ Бабосов Е.М. Энциклопедический словарь. Москва : Книжный дом, 2009. 480 с.

${ }^{15}$ Гришина Г.Б. Психология конфликта. Москва, 2002. 464 с.
} 
expressed in influentialness of his structure and connections, skill and ability, its social experience of conflict interaction.

2. Groups of support. Such participants, that is present in any conflict and can be represented by friends, colleagues and others like that.

3. Other participants of conflict are subjects that influence on course and results of conflict. Instigators and organizers could be mentioned here. Sometimes participants of conflict include mediators. The basic task of such third party is stopping the conflict.

4. The reason of conflict is existing problem that serves as basis of conflict, a reason for different parties for contradiction and entering into opposition.

5. The object of conflict can be a material, social or spiritual value, to possession or use of which both opponents aimed.

6. Micro- and macroenvironment of conflict are circumstances in which the participants of conflict operate. Taking into account surroundings of participants of conflict at micro- and macroenvironment level allows to understand their real aims, reasons of parties, and also their dependence on this environment ${ }^{16}$.

Furthermore, a structure of conflict is totality of its features that provide integrity, equality to the itself, difference from other phenomena of social life. Without the presence of these features a conflict can not exist as dinamically interdependent system and process.

In his turn, A. Drunie marks that an important aspect in a managing business conflicts resolution is their dynamics. It is necessary to point out that beginning of conflict can be fixed as the first acts of counteraction of parties. For starting of conflict three obligatory conditions taken together are needed: the first participant consciously acts against the second participant; the second participant realizes that that actions are directed against his interests; therefore he begins corresponding actions against the first participant. However, if the first side began aggressive actions, and second - remain in passive position, then a conflict will not take place ${ }^{17}$.

Analysing scientific work of D. Johnson, it is possible to distinguish the following periods and stages in the dynamics of business conflict :

16 Донцов А.И. Психология коллектива. Москва : Международный гуманитарный университет, 1994. 340 с.

17 Друньє А. Розв'язання конфліктів. Основні принципи успішного керівництва. Москва, 1999. 376 с. 
I. The Latent (pre-conflict) period includes such stages:

1. Origin of objective problem situation. Essence of such situation is in the origin of contradiction between subjects (by their aims, reasons, aspirations and other like that). Such situation is a problem in interaction but that contradiction is not yet realized and conflict actions are absent. A feature is that most problem situations exist for a long time, not coming out.

2. Realization of objective problem situation by the subjects of interaction. Essence of this stage is in that the subjects of conflict understand the necessity of resolution of contradiction. Subjective perception of problem situation is an obstacle for realization of interests by both parties of conflict. Mostly, exact social divergences of participants are the basis of subjectivity of perception of situation. To this category belong values, ideals and interests. On complication of situation speed of development and probability of distortion of events depend by opponents.

3. Attempts of parties to resolve an objective problem situation using unconflict methods. Contradiction of conflict situation is not precondition of conflict interaction of parties. Sometimes the subjects of conflict try to apply unconflict methods: persuasion, elucidation, request, informing. On this stage an argumentation takes place, expressing own interests and fixing of the position.

4. The origin of pre-conflict situation is characterized as a presence of threat for one of parties of conflict. The actions of opponent must be regarded as an instant danger, that assist to development of situation toward a conflict.

II. An open period (period of conflict interaction) or actually conflict includes the next stages:

1. An incident is the first collision of parties.

2. Escalation of conflict. This stage is characterized by sharp intensification of struggle between opponents.

3. Balanced interaction. On this stage activity of parties to resolve the conflict conflict becomes less intensive. Parties see unefficiency of power methods for the achievement of consent.

4. Completion of conflict. The basic difference of this stage from other consists in a transition from conflict interaction to stopping of conflict. Completion of conflict shows up in such forms: decision, settlement, fading, removal, outgrowing in other conflict. 
III. Postconflict period. This period consists of two stages: partial and complete normalization of relations between opponents ${ }^{18}$.

Above-mentioned periods and stages, that characterize the dynamics of business conflict help to understand that as well as other types of conflicts, a business conflict means the collision of sides. However a main difference is that opposition and cooperation of certain target group are taking place. The dynamics of business conflict in educational institutions represent the realized contradiction between the members of corresponding collective, that aspires to the emotional decision in a situation that was folded in interorganizational space.

It should be noticed that a business conflict is a conflict between subjects, that relate to educational institutions, and could be ordinary employee or leaders. Also the participants of business conflict can be separate subdivisions and organizations that connected with the sphere of education.

Therefore unlike other types of conflicts, namely business conflicts in educational institutions are bearing certain features. Firstly, there are differences of the functional systems of educational institutions. In comparing to society educational institutions is more local system. Exactly within the limits of such system there are rules, standards, well-regulated processes that come forward as mechanisms of coordinated behavior. Exactly this feature gives an opportunity for prognostication of conflict situations and reliable application of measures of preventive character. Secondly, important is a role-play structure of educational institutions and its workers. Everybody, in order to achieve certain goal in professional field, pulls out on the first plan professional qualities and inner position. In other words, the role of worker appears in organization, id est set of the expected behavioural stereotypes related to implementation of certain work. Thirdly, for a managing business conflicts in the field of education methods of management of personnel are important. The effective management of educational institutions requires precise application of methods, but development of organizational structure - general system of methods by means of which educational institution conducts distribution of labour process on separate tasks and arrives at co-ordination between these tasks. On the method of implementation of tasks in organization, it worth

18 Джонсон Д.В. Соціальна психологія : тренінг міжособистісного спілкування. Київ : Академія, 2003. 288 с. 
to mention the horizontal and vertical organizational structure of educational institutions. On the basis of horizontal differentiation is conducted the implementation of different tasks in relation to activity of or educational institution after distribution and grouping according to certain principles. The types of horizontal differentiation shows different tasks, for example implementation of work, promotion of educational services, choosing consumers of educational services, at the place of location of educational institution or its separate subdivision. Also educational institutions have vertical distribution. Vertical differentiation is determined by the number of levels of authority, division of administrative specialities. Exactly vertical differentiation influences on satisfaction of stuff of educational institutions.

It is also necessary to mark that managing business conflicts in the field of the management of educational institutions envisages three stages of work with a business conflict: confession of the real reasons of conflict parties / by one side; legitimization of conflict is an achievement of consent between the participants of conflict in relation to confession of the set rules of conflict interaction; institualization of conflict is creation of corresponding bodies in order to adjust conflict interaction ${ }^{19}$.

It is worth to mention that namely the stage of institutialisation is one of basic, in fact on this very stage the mechanism of adjusting of conflict that will be based on clear principles and realized by means of the worked out technologies is being created. Institualisation of conflict for the managers of education can serve as the measure of preventive character. Because such conflicts are predictable, id est it is possible to look after development of that. The process of institutialisation of conflict interaction consists of next stages: structuting of groups (resolving question of accordance of behavior to the transmitters of opposite interests) and reduction of conflict (gradual lowering of conflict by its translation on another level) ${ }^{20}$.

For business conflicts in the sphere of education destructive consequences are inherent, that is why it is necessary for an effective management to be able to diagnose the dynamics of conflict development, work out strategy of actions and provide it by means of

19 Турищева Л.В. Особливості педагогічних конфліктів. Англійська мова в початковій школі. 2006. Вип. 5. С. 6-9.

${ }^{20}$ Ширшов В.Д. Педагогическая коммуникация. Москва, 2001. 240 с. 
certain technological receptions, such as: comprehension of conflict; working out a conflict management; creating a mechanism of inhibition; creation of technologies of managing a conflict.

Analysing the above-mentioned, we underline certain basic principles of managing business conflicts exactly in the sphere of education:

- determination of reasons and pre-conditions of origin of conflict situation;

- strategically shaping an approach to management and resolution of business conflict;

- analysis of existing tools for resolution of conflict and choosing the most effective ones;

- structurisation of subjects of conflict for an objective management and prevention of destructive consequences of the conflict.

For the effective resolution of business conflicts in the sphere of education, it is necessary for the manager or head of an educational institution to apply the extended arsenal of methods of management conflicts. According to tools of conflict resolution we can differ the structural and interpersonal groups of methods. To the structural methods of conflict resolution we can attribute elucidation of requirements to work, using of co-ordinating and integration mechanisms, setting of common aims and use of the system of rewards. Interpersonal methods of conflict resolution in the sphere of educational management are the following: rejection, smoothing, compulsion, compromise, decision of problem ${ }^{21}$.

There are five existing basic styles of conflict resolution, based on the method of Thomas-Killmen. The system allows to work out individual style of conflict resolution. Such possibility exists because basic styles of behavior during a conflict are related to the general source - divergence of interests of two or more parties. Style of behavior of one of parties of conflict will be determined by measures that individual aims to satisfy his own interests and interests of opposite side (parties). The method of Thomas-Killmen envisages the next styles of conflict resolution:

1. Style of competition. Such style is effective only in case when one of the parties of conflict knows that its decision is correct. And in that case it has the opportunity to insist on it.

21 Лапин Г.Г. Социологический анализ организационных систем. Bonpocbl философии. 1974. Вып. 7. С. 38-49. 
7. Style of avoidance is being used in case when for one of the parties of conflict the meaning of a problem is not important and it has no desire to spend resources on its decision.

8. Style of adaptation will be useful if a business result is extraordinarily important for one of the parties of conflict.

9. Style of collaboration one of the hardest because requires a true collaboration. Both sides must be able to expound the necessities, hear each other and only then to lay down the alternative options of problem resolution. Such approach immediately becomes uneffective as soon as there is absent any of these elements ${ }^{22}$.

Analysing different approaches, principles, methods, postulates that are used for the resolution of business conflicts in educational institutions, it is impossible to find the only perfect way of conflict resolution. More promising apptoach is to investigate technologies of managing conflicts.

A successful management of conflict situations in the sphere of education is possible by developing relevant tactics, that will take into account the features of conflict. An important aspect is a search of general tangencies in interests of opponents. In fact this process is bilateral and turns out to be impossible in case of unwillingness (refuses) of opponents. It is important to discuss a problem objectively, finding out the essence of business conflict. In fact the successful search of method of resolution of problem in majoritymostly depends on ability of both sides to see the main and think structurally. For a leader it is important to choose optimal strategy of resolution of conflict situation that meets these circumstances.

For the foresight of development and management of a conflict, it is needed to thoroughly conduct the analytical stage - to investigate the object of conflict, opponents, reasons and direct occasion, that caused a conflict, social environment, secondary reflection. Only after the objective analysis of situation it is necessary to speculate on the options and ways of conflict resolution and to define necessary steps. It is also necessary to understand clearly the development of events as a result of choice of certain strategy and choose the latter according to the most favorable expected result.

22 Поляков А.Б. Конфликтная компетентность руководителя образовательного учреждения. Педагогическая мастерская. 2005. Вып. 4. С. 54-59. 
Giving prognosis on the development of events after the choice of strategy is possible using criteria of resolution of business conflict. Here one could refer to: legal forms, moral principles, opinion of authoritative persons, precedents of decision of analogical problems in the past. Realization of selected strategy takes place according to the select method.

Analysing all abovementioned about the resolution of business conflicts in the sphere of the management of educational institution, it is possible to outline possible tactics of manager of education: resolution of conflict on the basis of its essence; a resolution of conflict on the basis of its aims; resolution of conflict on the basis of its functions; resolution of conflict on the basis of emotionally-cognitive state of participants; resolution of conflict on the basis of properties of its participants; resolution of conflict on the basis of its possible consequences; resolution of conflict on the basis of ethics of relations between rival parties.

Leaning on that research, the system of methodical recommendations was worked out regarding management of business conflicts in educational instiyutions : to do public statements that one of parties of conflict wants to stop escalation of conflict; to conduct elucidation, according to the pre-arranged steps for normalization of relations between parties of conflict; to induce opponents to the exchange acts that will assist the resolution of situation; to conduct preventive events with explanation, that business conflicts are uneffective for all their participants, to specify on reliable consequences; to offer strategies of decision and ways of stopping of business conflicts.

\section{CONCLUSIONS}

Management of a general educational institution is carried out by its director, who is appointed by a public administration body. His duties are clearly defined in the Provision on the general educational institution, which states that the director ensures the implementation of the state educational policy, disposes of school property and funds in the established procedure, approves the budget and its implementation, concludes agreements, opens accounts in banks, manages loans, issues orders binding on all participants in the educational process, organizes and controls the educational process, is responsible for the quality of the work of the teaching staff, the protection of childhood and work, creates 
conditions for extracurricular and extracurricular educational work, appoints and dismisses its deputies and pedagogical workers, approves their official duties and rules of the internal order (together with the trade union committee), creates conditions for the creative growth of teaching staff, is responsible for their activities in front of the team of the school, parents, local authorities.

The main functions of the managerial activity of the director of a general educational institution are the pedagogical analysis of the state of the educational process in the school, the planning of the work, the organization of the school's activities, the intra-school control and the regulation of the life of the school team. The cycle of management of the school begins with the pedagogical analysis of work in the previous period and evaluation of its effectiveness, namely: what gave the activity to managers and teachers; what appeared new in the actions of teachers, life classes, students; how carried out work contributed to the education of students of national consciousness and high moral qualities; what mistakes were made by managers; how optimal was the control. The function of pedagogical analysis provides the basis for planning.

Planning is the main point for management, which means designing the educational process and the process of guidance, defining goals and objectives. Organization of internal school management is the next function - it is putting into action the managerial decision, the implementation of the plan in life. This work consists of choosing the most appropriate forms and methods depending on the timing, arrangement of performers, their business qualities and experience and the provision of guidance.

Control is one of the main means of providing reliable and reliable information about the state of educational work. When conducting the control, it is necessary to observe the relationship and interconnection of forms and time with the content of the educational process, the differentiated approach to objects, the comprehensiveness and depth of coverage of the object of control, systematic and consistent, verification of execution and publicity, the dynamism of forms and methods, involvement in public control.

Today we need a deep study of the educational process, the very essence of interaction between teachers and students, diagnosis of levels of activity of students in teaching, work and communication, and 
provision of timely assistance to the managers of the educational process, making corrections in their activities. And, first of all, the managerial activity in the general educational institution should be aimed at managing not only pupils but also pedagogical personnel, eliminating the causes and consequences of various professional destructions. Democratization in the regulatory process is manifested in the fact that the manager engages teachers and students in collecting and analyzing information about the state of the educational process. Regulation is operative (operational meetings with the director, deputy), thematic (production meetings, pedagogical councils), final (pedagogical council on the results of the academic year, semester, conference). Management functions are organizationally united, the loss of one of the functions negatively affects the management cycle or suspends its execution.

The success of managing a school depends on the position of the director, the style of his work, his competence, and the belief in the need to democratize management. The director-democrat recognizes the need for school councils, tolerates criticism, knows how to conduct a dialogue, does not oppose a team, rely on collective opinion, act deliberately and consistently.

As a result of analysis, we came to the next conclusions: firstly, a concept "business" is investigated enough in socio-humanitarian sciences, also modern scientific literature holds in a spotlight the different aspects of business conflicts. The analysis of approaches to resolution of conflict showed that a business conflict is the conflict based on contradictions directly in the field of professional activity. Furhthermore, a business conflict is being unfolded and resolved in a certain professional situation in touch with the origin of professional problem and has certain reasons, transmitters, owns certain functions, duration and measure of sharpness. The analysis of features of business conflicts in the field of the management of educational institutions gives an opportunity to understand that the difference of business conflicts from other types of conflict is determined by three basic moments : by the differences of the functional systems of educational institution; by the role-play structure of educational institution and by methods of management a personnel.

Taking into account realities of public life, it was certain that a process of management a business conflict is a purposeful influence on 
the dynamics of conflict. An administrative process includes the certain types of activity, such as a prophylaxis and prevention of origin of business conflicts, diagnostics and adjusting of conflict, prognostication of development of conflicts and estimation their functional orientation and possible consequences, process of resolution of conflict. There is plenty of methods and technologies of a managing and resolving business conflicts. It is crucial for leaders in the sphere of education to master on general rules, principles and recommendations for effective application in case conflict situation evolved. Professionalism in making a decision in conflict situations will give possibility to the managers of educational sphere to regulate structurally conflict interaction and to use principles of effective interpersonal business communication.

\section{SUMMARY}

The article is approaching the problem of managing a general educational institution (also known as secondary, or comprehensive school). It presents the analysis of different generalizations connected with the definition of the concepts of «management» and «managerial activity». Disclosing of the peculiarities and specific features of managing an educational institution is being proposed. The analysis of the principles and structure of managerial activity, its planning, role of control and recommendations for improving the management in the general educational institutions are given. The article also analyzes the problem of managing business conflicts in educational institutions. An analysis of scientific views on the definition of the concept of "conflict" and "business conflict" is presented. Specific features of inner conflicts in educational institutions are disclosed. The peculiarities of the structure of business conflicts, the dynamics of their development, and recommendations for improving the management of business conflicts in educational institutions are given.

\section{REFERENCES}

1. Анцупов A.I., Шипілов А.І. Конфліктологія. Москва : ЮHITI, 2000. $551 \mathrm{c}$.

2. Бабосов Е.М. Энциклопедический словарь. Москва : Книжный дом, 2009. 480 с.

3. Гришина Г.Б. Психология конфликта. Москва, 2002. 464 с. 
4. Деркач А.А. Акмеологические основы управленческой деятельности. Москва, 2000. Т. 2. 536 с.

5. Донцов А.И. Психология коллектива. Москва : Международный гуманитарный университет, 1994. 340 с.

6. Друньє А. Розв'язання конфліктів. Основні принципи успішного керівництва. Москва, 1999. 376 с.

7. Джонсон Д.В. Соціальна психологія : тренінг міжособистісного спілкування. Київ : Академія, 2003. 288 с.

8. Зельке Д.С., Віллерман М. Конфлікти та їх розв'язання у початковій школі. Суми, 1992. 164 с.

9. Кравченко О.П. Погляд конфліктолога на онтосинтез конфлікту. Соціологічні дослідження. 2004. Вип. 9. С. 103-112.

10. Коломонський Н.Л. Психологія менеджменту в освіті (соціально-психологічний аспект) : автореф. дис. ... д. псих. наук : 19.00.05. Київ, 2001. 37 с.

11. Кузьмина Н.В., Паутова Л.Е., Пожарский С.Д. Акмеология качества профессиональной деятельности специалиста : монография. Санкт-Петербург, 2008. 376 с.

12. Лапин Г.Г. Социологический анализ организационных систем. Bопросы философии. 1974. Вып. 7. С. 38-49.

13. Линкольн У. Переговоры. Рига, 1998. 189 с.

14. Маслов B.I. Наукові основи та функції управління загальноосвітніми навчальними закладами. Тернопіль : Астон, 2007. 150 с.

15. Маслов B.I. Принципи менеджменту в установах освіти. Освіта і управління. 1997. Вип. 1. С. 77-84.

16. Педагогіка : модульний курс / І.П. Анєнкова та ін. Львів : Новий Світ, 2010. 567 с.

17. Поляков А.Б. Конфликтная компетентность руководителя образовательного учреждения. Педагогическая мастерская. 2005. Вып. 4. С. 54-59.

18. Сміт А. Дослідження про природу i причини багатства народів. Москва, 1993. 205 с.

19. Тищенко О.I. Феномен керівництва та лідерства в системі управлінської діяльності. URL: http://www.nbuv.gov.ua/portal/soc_ gum/pfto/2010_9/files/pd910_31.pd (дата звернення: 01.06.2019)

20. Турищева Л.В. Особливості педагогічних конфліктів. Англійська мова в початковій школі. 2006. Вип. 5. С. 6-9. 
21. Фишер Р. Путь к согласию. Москва, 1990. 312 с.

22. Ширшов В.Д. Педагогическая коммуникация. Москва, 2001. $240 \mathrm{c}$.

Information about the author:

Dolzhenkov O. A.

Doctor of Political Science, Professor,

Head of the Department of Educational Management and Public Administration, South-Ukrainian National Pedagogical University named after K.D. Ushynskiy 26, Staroportofrankivska str., Odesa, 65000, Ukraine 